\title{
Dose-dependent effects of genistein on bone homeo- stasis in rats' mandibular subchondral bone
}

\author{
Yong-qi $\mathrm{LI}^{1, \#}$, Xiang-hui XING ${ }^{2, \#}$, Hui WANG ${ }^{2}$, Xi-li WENG ${ }^{2}$, Shi-bin $\mathrm{YU}^{2, *}$, Guang-ying DONG ${ }^{2, *}$ \\ ${ }^{1}$ Xijing Hospital, Fourth Military Medical University, Xi'an 710032, China; ${ }^{2}$ School of Stomatology, Fourth Military Medical University, \\ Xi'an 710032, China
}

\begin{abstract}
Aim: To investigate the effect of genistein on bone homeostasis in mandibular subchondral bone of rats. Methods: Female SD rats were administered with genistein (10 and $50 \mathrm{mg} / \mathrm{kg}$ ) or placebo by oral gavage for 6 weeks. Then the animals were sacrificed, and histomorphology and micro-structure of mandibular condyle were examined using HE staining and micro-CT analysis, respectively. The expression levels of alkaline phosphatase (ALP), osteocalcin (OC), osteoprotegerin (OPG), the receptor activator of nuclear factor $\mathrm{KB}$ ligand (RANKL) and estrogen receptors (ERs) in mandibular condyle were detected using real-time PCR. Cultured osteoblasts were prepared from rat mandibular condyle for in in vitro study. The cells were treated with genistein $\left(10^{-7}\right.$ or $10^{-4}$ $\mathrm{mol} / \mathrm{L}$ ) for $48 \mathrm{~h}$. The expression of the bone homeostasis-associated factors and estrogen receptors (ERs) was detected using realtime PCR, and ER silencing was performed.

Results: At both the low- and high-doses, genistein significantly increased the bone mineral density (BMD) and bone volume, and resulted in thicker subchondral trabecular bone in vivo. In both in vivo and in vitro study, the low-dose genistein significantly increased the expression of ALP, OC and OPG, but decreased the expression of RANKL and the RANKL/OPG ratio. The high-dose genistein decreased the expression of all these bone homeostasis-associated factors. Both the low and high doses of genistein significantly increased the expression of ER $\beta$, while ER $\alpha$ expression was increased by the low dose genistein and decreased by the high dose genistein. ERß silencing abrogated most of the effects of genistein treatment.

Conclusion: In rat mandibular condylar subchondral bone, low-dose genistein increases bone formation and inhibit bone resorption, while excess genistein inhibits both bone formation and resorption. The effects of genistein were predominantly mediated through ERß.
\end{abstract}

Keywords: genistein; estrogen receptor; mandibular subchondral bone; osteoblast; alkaline phosphatase; osteocalcin; osteoprotegerin; the receptor activator of nuclear factor $\mathrm{KB}$ ligand (RANKL)

Acta Pharmacologica Sinica (2012) 33: 66-74; doi: 10.1038/aps.2011.136; published online 28 Nov 2011

\section{Introduction}

Osteoporosis is a systemic disease characterized by reduced bone mass and structural deterioration of bone tissue. Osteoporosis has become a public health issue threatening a large portion of the population over 50 years of age $\mathrm{e}^{[1,2]}$. Estrogen replacement therapy (ERT) is effective in reducing or reversing postmenopausal bone loss ${ }^{[3]}$. In addition to its use for the treatment of postmenopausal symptoms, potential benefits of ERT include a reduction in the risk of osteoarthritis ${ }^{[4-6]}$ and prevention of cardiovascular disease and dementia ${ }^{[7]}$. However, recent studies have shown that ERT is associated with

\footnotetext{
\#These authors contributed equally to this work.

* To whom correspondence should be addressed.

E-mail yushibin@fmmu.edu.cn (Shi-bin YU); donggy@fmmu.edu.cn (Guang-ying DONG)

Received 2011-07-23 Accepted 2011-09-15
}

a higher risk for breast, endometrial and ovarian cancer as well as cardiovascular disease and stroke ${ }^{[8,9]}$. Due to the sideeffects of long-term ERT use, the number of ERT users has fallen dramatically.

Observational studies suggest that Asian women who consume traditional diets high in isoflavones from soybean have a lower rate of postmenopausal fractures than Caucasian women $^{[10,11]}$. Phytoestrogen, especially genistein, which structurally resembles $17 \beta$-estradiol, is abundant in soybean products. Previous animal studies have shown that genistein treatment increased bone mineral density (BMD) and improved bone biomechanical performance in ovariectomized (OVX) rodents $^{[12,13]}$. Clinical studies have also demonstrated that phytoestrogen can effectively increase the BMD of vertebrae and hip bones in postmenopausal women without side effects, which suggested that genistein plays an important role in the regulation of bone formation and bone resorption ${ }^{[14-17]}$. phos- 
phatase (ALP) and osteocalcin (OC) are widely used markers for bone formation. Genistein treatment $(45 \mathrm{mg} / \mathrm{kg}$ by oral gavage) was observed to significantly increase the serum ALP and OC levels in OVX rats ${ }^{[18]}$. In the process of bone resorption, osteoprotegerin (OPG) and the receptor activator of nuclear factor $\mathrm{kB}$ ligand (RANKL) constitute a complex mediator system. The RANKL to OPG ratio is the key regulatory determinant of bone resorption ${ }^{[19]}$. It is suggested that genistein $(10 \mathrm{mg} / \mathrm{kg}$, subcutaneous administration) significantly increased serum OPG level as well as decreased serum RANKL level and the RANKL/OPG ratio in OVX rats ${ }^{[20]}$. Additionally, the most abundant protein in bone is type I collagen. Type I collagen carboxy terminal telopeptide (CTX) is formed during bone collagen breakdown and is liberated into the circulation. Serum concentration of CTX reflects the degree of bone resorption ${ }^{[21]}$.

In the literature, the effects of genistein on bone were almost exclusively focused on changes in long bones or lumbar spines in OVX animals or postmenopausal women with estrogen deficiency. It has been suggested that patients with a history of osteoporotic fractures tend to have increased mandibular bone loss and relevant trabecular micro-structural changes ${ }^{[22]}$. Additionally, a dense trabecular pattern in the mandibular alveolar process has been proven to be a reliable sign of normal BMD in dentate middle-aged subjects whereas a sparse trabecular pattern indicates osteopenia ${ }^{[23]}$. In developed countries, a large proportion of the population visits dentists annually, and dental radiographs are performed routinely. Thus, researchers worldwide have recently tried to develop methods for using the jawbones, especially the mandible, to predict skeletal $\mathrm{BMD}^{[23]}$. The mandibular condyle, one important section of the mandible, is one of the most common sites of $\mathrm{OA}^{[24]}$. Furthermore, the articular surfaces of the mandibular condyle are composed of fibrocartilage that is distinct from the hyaline cartilage of the appendicular skeleton ${ }^{[25]}$. Unlike appendicular joints whose cartilage and subchondral bone are separated by tidemark and calcified cartilage, mandibular condylar cartilage and its subchondral bone are not obviously separated by an osteochondral interface ${ }^{[26]}$. However, in the literature few reports focused on the effect of phytoestrogens on mandibular bone, particularly in intact animals with normal estrogen levels. How genistein affects bone homeostasis in mandibular subchondral bone and whether different doses of genistein play different roles in this process remain unclear. The aim of the present study was to investigate the effect of different doses of genistein on bone homeostasis in the mandibular condylar subchondral bone in intact female rats.

\section{Materials and methods}

\section{Genistein treatment in vivo}

All experimental procedures administered to the animals were approved by the Animal Research Committee of the Fourth Military Medical University. Thirty female 7-weekold SD rats, weighing 180-190 g, were provided by the animal center of the Fourth Military Medical University. All animals were housed under conditions of $22^{\circ} \mathrm{C}$ and $30 \%-60 \%$ relative humidity with a normal day-night rhythm, consisting of a $12 \mathrm{~h}: 12 \mathrm{~h}$ light-dark cycle. Animals were randomly assigned into the control, low- or high-dose genistein-treated groups, 10 animals in each group. Rats had free access to tap water and a phytoestrogen-free diet where corn oil replaced soybean oil. Based on a series of safety studies with genistein, it is estimated that the no observed adverse effect level (NOAEL) of genistein is $50 \mathrm{mg} \cdot \mathrm{kg}^{-1} \cdot \mathrm{d}^{-1}$ for rats, and the no observed effect level (NOEL) is $10 \mathrm{mg} \cdot \mathrm{kg}^{-1} \cdot \mathrm{d}^{-1}[27$. Thus, in the present study, $50 \mathrm{mg} \cdot \mathrm{kg}^{-1} \cdot \mathrm{d}^{-1}$ genistein was chosen as the high dose, and 10 $\mathrm{mg} \cdot \mathrm{kg}^{-1} \cdot \mathrm{d}^{-1}$ as the low dose. The animals were treated once daily with genistein (10 or $50 \mathrm{mg} / \mathrm{kg}$ body weight, $99.5 \%$ pure, Winherb Med Sci Co Ltd, China) or placebo by oral gavage. Genistein was dissolved in a placebo solution $(0.9 \% \mathrm{NaCl}, 2 \%$ Tween 80 , and $0.5 \%$ methyl cellulose in water). Application volume was $5 \mathrm{~mL} / \mathrm{kg}$ body weight. Changes in body weight during the experimental period were taken into account in calculating the genistein dosage. All animals were sacrificed following 6 weeks of genistein administration.

\section{Histological analysis}

Under deep anesthesia, 12 rats (4 in each group) were sacrificed for histological analysis. The right temporomandibular joints (TMJs), including the mandibular ramus, were dissected and fixed in $4 \%$ paraformaldehyde $(\mathrm{pH} 7.4)$ overnight at $4{ }^{\circ} \mathrm{C}$ and then decalcified for 1 week in Kristensen's fluid (sodium formate $52.2 \mathrm{~g}$, formic acid $174.2 \mathrm{~mL}, 1000 \mathrm{~mL}$ distilled water). Samples were then dehydrated and embedded in paraffin, followed by cutting into $5 \mu \mathrm{m}$ middle-sagittal sections. HE staining was carried out for histological analysis. As we previously reported ${ }^{[26]}$, two square areas $(0.5 \mathrm{~mm} \times 0.5 \mathrm{~mm})$ were selected under the interface of the cartilage and subchondral bone. They were located in the center of the middle and posterior third sections of the condylar cartilage that appeared consistent among animals. Using a computer-assisted image analyzing system (Leica Qwin Plus, Leica Microsystem Imaging Solutions Ltd, Cambridge, United Kingdom), the 2D measurements within the selected squares were performed by directed measurement of the trabecular bone area (B.Ar in $\mathrm{mm}^{2}$ ) and perimeter (B.Pm in $\mathrm{mm}$ ). Then, the histomorphometric parameters of the subchondral trabecular bone were calculated according to Parfitt's formula as follows: bone volume fraction $(\mathrm{BV} / \mathrm{TV})=\mathrm{B}$. Ar $/ \mathrm{T}$. Ar; trabecular thickness $(\mathrm{Tb} . \mathrm{Th})=\mathrm{B} . \mathrm{Ar} / \mathrm{B} . \mathrm{Pm}$; trabecular number $(\mathrm{Tb} . \mathrm{N})=\mathrm{B} \cdot \mathrm{Pm} / \mathrm{T} . \mathrm{Ar}$; trabecular separation $(\mathrm{Tb} . \mathrm{Sp})=(\mathrm{T} . \mathrm{Ar}-\mathrm{B} . \mathrm{Ar}) / \mathrm{B} . \mathrm{Pm}$. The means of the data from two squares were used for statistical analysis.

\section{Micro-computed tomography (micro-CT) analysis}

As reported previously ${ }^{[26]}$, the left mandibular condyles from animals for histological analysis were scanned in a micro-CT system (GE eXplore Locus SP, London, UK) at an isotropic spatial resolution of $8 \mu \mathrm{m}$ and a peak voltage of $80 \mathrm{kV}$. Twelve condyles, 4 in each group, were inserted in parallel into a home-made, round synthetic foam and mounted in the cylindrical specimen holders. Four projections were performed for each scan angle in each slice. These projections had an 
exposure time of $3000 \mathrm{~ms}$ each and were averaged in order to improve the signal-to-noise ratio. The time of each scanning was over $270 \mathrm{~min}$. General Electric Health Care MicroView ABA 2.1.2 Software was used to analyze reconstructive images of condyles and to calculate the parameters of architecture and mineralization. Similar to histomorphometric analysis, the interface of the cartilage and subchondral bone was divided into anterior, middle and posterior regions. As shown in Figure 1 , two cubic regions of interest (ROI) $(0.5 \mathrm{~mm} \times 0.5 \mathrm{~mm} \times 0.5$ $\mathrm{mm}$ ) were selected in the center of the middle and posterior regions of the condyle for the model-independent, threedimensional morphometric analysis (Figure 1). The following micro-structural parameters were obtained: 1) BMD; 2) BMC; 3) trabecular bone volume fraction (BV/TV); 4) bone surfaceto-volume ratio (BS/BV); 5) mean trabecular thickness (Tb.Th); 6) trabecular number (Tb.N), 7) mean trabecular separation (Tb.Sp), and 8) bone volume (BV). The means of the data from two ROIs were used for statistical analysis.
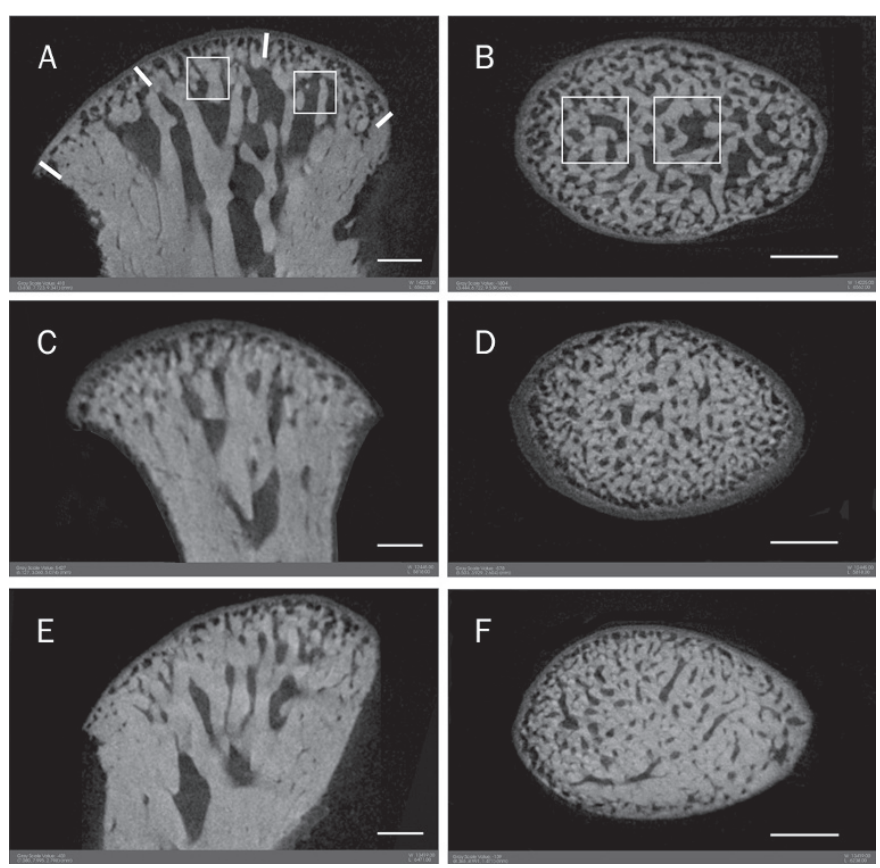

Figure 1. Sagittal central and coronal section of mandibular condyle scanned by micro-CT. A and B from control group, C and D from low dose genistein-treatment group, and $\mathrm{E}$ and $\mathrm{F}$ from high dose genisteintreatment group. The area of trabecular bone in both genistein-treatment groups was obviously higher than that in control group. White cubes in $A$ and $B$ represented the selected regions of interest for three-dimensional morphometric analysis. Scale bar is $500 \mu \mathrm{m}$.

\section{Quantitative real-time PCR in vivo}

Under deep anesthesia, the remaining 18 rats (6 in each group) were sacrificed for real-time PCR. Twelve mandibular condyles in each group were randomly assigned into 3 samples. Mandibular condylar subchondral bone samples were pulverized in liquid nitrogen. The total RNA was isolated using a standard TRIzol ${ }^{\circledR}$ protocol (Invitrogen, Carlsbad, CA, USA), followed by first-strand cDNA synthesis with the RevertAid ${ }^{\mathrm{TM}}$ First Strand cDNA Synthesis Kit (Fermentas). Real-time PCR was performed in an ABI 7500 Fast thermal cycler. The protocol comprised 40 cycles of $94^{\circ} \mathrm{C}$ for $5 \mathrm{~s}, 62^{\circ} \mathrm{C}$ for $34 \mathrm{~s}$, and $72{ }^{\circ} \mathrm{C}$ for $1 \mathrm{~min}$ each. The detected cytokines were ALP, OC, OPG, RANKL, ERa, and ER $\beta$. Table 1 shows the sequences of the primers used in this study. Expression levels of all detected cytokines were normalized according to ribosomal protein 18S RNA levels to account for differences arising from reverse transcription efficiency and quality of the total $\mathrm{RNA}^{[28]}$.

Table 1. Primer sequences for ALP, OC, OPG, RANKL, ER $\alpha, E R \beta$, and S18.

\begin{tabular}{|c|c|c|c|}
\hline Gene & Sequence & $\begin{array}{l}\text { Fragment } \\
\text { length (bp) }\end{array}$ & $\begin{array}{c}\text { Accession } \\
\text { number }\end{array}$ \\
\hline \multirow[t]{2}{*}{ ALP } & F: 5'-CGAGCAGGAACAGAAGTTTGC-3' & $105 \mathrm{bp}$ & NM_013059 \\
\hline & R: 5'-TGGCCAAAAGGCAGTGAATAG-3' & & \\
\hline \multirow[t]{2}{*}{$\mathrm{OC}$} & F: 5'-ATGCCACTGCGTATTGGTTGA-3' & $122 \mathrm{bp}$ & M25490 \\
\hline & R: 5'-TCCGCTAGCTCGTCACAATTG-3' & & \\
\hline \multirow[t]{2}{*}{ OPG } & F: 5'-AGCTGGCACACGAGTGATGAA-3' & $106 \mathrm{bp}$ & U94330 \\
\hline & R: 5'-CACATTCGCACACTCGGTTGT-3' & & \\
\hline \multirow[t]{2}{*}{ RANKL } & F: 5'-GGAGGATTTTTTCAAGCTCCGG-3' & $103 \mathrm{bp}$ & NM_057149 \\
\hline & R: 5'-TGAAAGCCCCAAAGTACGTCG-3' & & \\
\hline \multirow[t]{2}{*}{$\mathrm{ER} \alpha$} & F: 5'-TGCGCAAGTGTTACGAAGTGG-3' & $108 \mathrm{bp}$ & NM_012689 \\
\hline & R: 5'-TTCGGCCTTCCAAGTCATCTC-3' & & \\
\hline \multirow[t]{2}{*}{ ERß } & F: 5'-AAAAACTCACCGTCGAGCCTT-3' & $124 \mathrm{bp}$ & NM_012754 \\
\hline & R: 5'-GCTGAATACTCATGGCGGTTG-3' & & \\
\hline \multirow[t]{2}{*}{ S18 } & F: 5'-CGGCTACCACATCCAAGGAA-3' & $187 \mathrm{bp}$ & M11188 \\
\hline & R: 5'-GCTGGAATTACCGCGGCT-3' & & \\
\hline
\end{tabular}

ALP, alkaline phosphatase; OC, osteocalcin; OPG, osteoprotegerin; RANKL, receptor activator of nuclear factor $\mathrm{kB}$ ligand; $E R \alpha$, estrogen receptor $\alpha$; $E R \beta$, estrogen receptor $\beta$; S18, ribosomal protein $S 18$, a housekeeping gene.

\section{Serum chemistry}

Before animals were sacrificed, blood was taken from the abdominal aorta by puncture exsanguination. Serum was collected by centrifugation and stored at $-80^{\circ} \mathrm{C}$ for further biochemical analysis. Serum bone-ALP, OC, OPG, RANKL, and CTX levels were measured by enzyme-linked immunosorbent assay (ELISA) using commercial kits (CSB-E11865r, CSB-E05129r, CSB-E07404r, and CSB-E05126r from Cusabio Biotech Co, Ltd, and QRCT-301330013301EIA \UTL from Adlitteram Diagnostic Laboratories) according to the manufacturer's instructions. The absorbance was read on an Elx800 ${ }^{\mathrm{TM}}$ microplate spectrometer (Bio-tec).

\section{Culture of primary osteoblasts and genistein treatment in vitro}

Primary osteoblasts were obtained from the mandibular subchondral bone of 8 -week-old SD rats. In brief, the mandibular condyles were dissected with aseptic technique. The soft tissues and cartilage were removed to obtain mandibular subchondral bone, which was reduced to small fragments and 
gently digested at $37^{\circ} \mathrm{C}$ with $0.125 \%$ trypsin for $8 \mathrm{~min}$. The digestion process was repeated 6 times. Fractionated cells were collected from the final four digestions and combined together as the primary osteoblasts. Cells were plated at a density of $1 \times 10^{4} / \mathrm{cm}^{2}$ into appropriate dishes and then cultured under $37^{\circ} \mathrm{C}$ and $5 \% \mathrm{CO}_{2}$ conditions. Culture medium was DMEM containing 10\% FBS, $100 \mathrm{U} / \mathrm{mL}$ penicillin and 100 $\mathrm{U} / \mathrm{mL}$ streptomycin. The cell medium was changed every three days.

For experiments, osteoblasts from the second generation were seeded in 12-well plates at a concentration of $3 \times 10^{4} / \mathrm{cm}^{2}$. It has previously been identified that genistein increases OPG levels with a maximum effect at $10^{-7} \mathrm{~mol} / \mathrm{L}^{[29]}$. Thus, in the present study, $10^{-7} \mathrm{~mol} / \mathrm{L}$ genistein was regarded as physiological or low dose, and $10^{-4} \mathrm{~mol} / \mathrm{L}$ as the high dose in vitro. At confluence, cells were treated with 0.1\% DMSO (Sigma D-2650) or genistein $\left(10^{-7}\right.$ and $10^{-4} \mathrm{~mol} / \mathrm{L}$, Sigma G6649) for an additional $48 \mathrm{~h}$. Cells were collected for total RNA isolation. The mRNA expression levels of ALP, OC, OPG, RANKL, ERa, and ER $\beta$ were evaluated by real-time PCR.

\section{RNAi of ERs and genistein treatment}

Small interfering RNA (siRNA) duplexes targeted against rat ERa and ER $\beta$ genes were designed and synthesized by Gene-Pharma (Shanghai, China). The siRNA sequences for ERa (GeneBank Accession No NM 012689) were as follows: sense, 5'-GGGAGCUGGUUCAUAUGAUTT-3' and antisense, 5'-AUCAUAUGAACCAGCUCCCTT-3'. The siRNA sequences for ER $\beta$ (GenBank Accession № NM 012754) were as follows: sense, 5'-GAGCACACCUUACCUGUAATT-3' and anti-sense, 5'-UUACAGGUAAGGUGUGCUCTT-3'. The nonsense siRNA sequences were as follows: sense, $5^{\prime}$-UUCUCCGAACGUGUCACGUTT-3' and anti-sense, 5'-ACGUGACACGUUCGGAGAATT-3'. Briefly, cells were grown in 6-well plates for $36 \mathrm{~h}$ and transfected at 70\%-80\% confluency. ERa and ER $\beta$ siRNAs were transfected with Lipofectamine 2000 (Invitrogen), respectively. Transfection medium was replaced after $6 \mathrm{~h}$. At confluence, cells were treated with $0.1 \%$ DMSO (Sigma D-2650), $10^{-7} \mathrm{~mol} / \mathrm{L}$ or $10^{-4} \mathrm{~mol} / \mathrm{L}$ genistein for another $48 \mathrm{~h}$. Cells were collected for total RNA isolation. The mRNA expression levels of ALP, OC, OPG, and RANKL mRNA were evaluated by real-time PCR.

\section{Statistical analysis}

SPSS 13.0 (SPSS Inc, Chicago, IL, USA) was used to analyze and describe the data. Single-factor analysis of variance was adopted. When significant main effects were found, specific comparisons between groups were made by Student's $t$ test. $P$-values were considered to be statistically significant when less than 0.05 .

\section{Results \\ Morphology and micro-architectural properties of mandibular condylar subchondral bone}

In the mandibular condyles of control, low-, and high-dose genistein-treated groups, condylar cartilage covering subchondral bone was arranged regularly with good continuity in each layer (Figure 2). As identified by histomorphological analysis, the mandibular subchondral trabecular bone became larger and thicker after both high- and low-dose genistein treatment (Table 2), which was also identified by micro-CT (Figure 1). As shown in Table 3, genistein induced significant increase in $\mathrm{BMD}, \mathrm{BMC}$, and bone volume in both the low-dose $(P<0.05$, $P<0.05, P<0.01$, respectively) and high-dose genistein-treated groups (all $P<0.01$ ). The BMD in the high-dose genisteintreated group was higher than that in the low-dose group $(P<0.05)$. With respect to the micro-architecture of subchondral bone, the BV/TV and Tb.Th increased in both low-dose $(P<0.05, P<0.01)$ and high-dose genistein-treated groups (both $P<0.01)$, as well as obvious decrease in BS/BV, Tb.N and Tb.Sp in both genistein-treated groups $(P<0.05, P<0.01)$. The BV/TV

Table 2. Values of the histomorphological parameters after genistein treatment. Mean \pm SEM. ${ }^{\mathrm{b}} P<0.05,{ }^{\mathrm{c}} P<0.01$ vs control group. ${ }^{\mathrm{e}} P<0.05$, ${ }^{\mathrm{f}} P<0.01$ vs low dose $(10 \mathrm{mg} / \mathrm{kg})$ genistein-treatment groups.

\begin{tabular}{lrrr}
\hline Parameters & Control group & $\begin{array}{c}\text { Genistein } \\
(10 \mathrm{mg} / \mathrm{kg})\end{array}$ & $\begin{array}{c}\text { Genistein } \\
(50 \mathrm{mg} / \mathrm{kg})\end{array}$ \\
\hline BV/TV $(\%)$ & $57.76 \pm 2.35$ & $63.15 \pm 2.92^{\mathrm{b}}$ & $72.4 \pm 3.37^{\text {cf }}$ \\
Tb.Th $(\mu \mathrm{m})$ & $58.02 \pm 4.66$ & $75.45 \pm 5.02^{\mathrm{c}}$ & $83.18 \pm 3.45^{\mathrm{ce}}$ \\
Tb.N $\left(\# / \mathrm{mm}^{3}\right)$ & $114.73 \pm 2.31$ & $9.34 \pm 0.88^{\mathrm{c}}$ & $9.03 \pm 0.81^{\mathrm{c}}$ \\
Tb.Sp $(\mu \mathrm{m})$ & $45.64 \pm 4.35$ & $29.52 \pm 2.88^{\mathrm{c}}$ & $26.48 \pm 3.35^{\mathrm{c}}$
\end{tabular}

BV/TV, trabecular bone volume fraction; Tb.Th, mean trabecular thickness; Tb.N, mean trabecular number; Tb.Sp, mean trabecular separation.
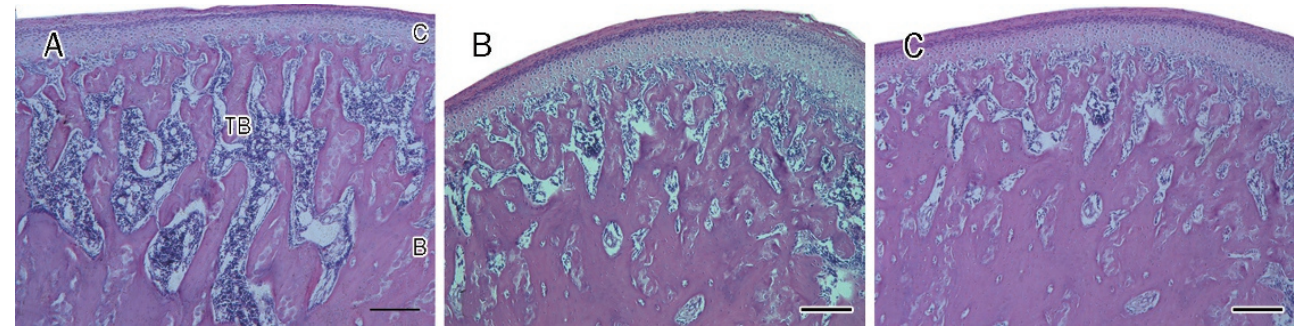

Figure 2. The histological morphology of mandibular condyle. (A-C) showed the morphology of middle-posterior region of mandibular condyle from control, low dose and high dose genistein-treatment groups. The area of trabecular bone in genistein-treatment group was obviously higher than that in control group. The space between trabecular bones in genistein-treatment group was obviously less than that in control group. C, cartilage; B, subchondral bone; TB, trabecular bone. Scale bar is $200 \mu \mathrm{m}$. 
Table 3. Values of BMD and microstructural parameters after genistein treatment. Means \pm SEM. ${ }^{b} P<0.05,{ }^{\circ} P<0.01$ vs control group. ${ }^{e} P<0.05,{ }^{f} P<0.01$ vs low dose $(10 \mathrm{mg} / \mathrm{kg})$ genistein-treatment groups.

\begin{tabular}{|c|c|c|c|}
\hline Parameters & Control group & Genistein (10 mg/kg) & Genistein $(50 \mathrm{mg} / \mathrm{kg})$ \\
\hline $\mathrm{BMD}\left(\mathrm{mg} / \mathrm{mm}^{3}\right)$ & $761.273 \pm 38.076$ & $887.893 \pm 31.714^{b}$ & $993.276 \pm 47.386^{\mathrm{ce}}$ \\
\hline $\mathrm{BMC}(\mathrm{mg})$ & $0.097 \pm 0.004$ & $0.111 \pm 0.007^{\mathrm{b}}$ & $0.124 \pm 0.008^{c}$ \\
\hline Bone volume $\left(\mathrm{mm}^{3}\right)$ & $0.079 \pm 0.002$ & $0.089 \pm 0.005^{c}$ & $0.093 \pm 0.004^{c}$ \\
\hline $\mathrm{BV} / \mathrm{TV}(\%)$ & $61.297 \pm 1.903$ & $67.228 \pm 2.578^{\mathrm{b}}$ & $73.568 \pm 1.782^{\text {cf }}$ \\
\hline Tb.Th $(\mu \mathrm{m})$ & $61.748 \pm 1.444$ & $72.794 \pm 1.999^{\circ}$ & $77.593 \pm 7.111^{\circ}$ \\
\hline Tb.Sp $(\mu \mathrm{m})$ & $0.102 \pm 3.654$ & $31.204 \pm 1.504^{c}$ & $28.176 \pm 1.850^{c e}$ \\
\hline
\end{tabular}

BMD, bone mineral density; BMC, bone mineral content; BV/TV, trabecular bone volume fraction; BS/BV, bone surface-to-volume ratio; Tb.Th, mean trabecular thickness; Tb.N, trabecular number; Tb.Sp, mean trabecular separation; BV, bone volume.

in the high-dose genistein-treated group was higher than that in low-dose group $(P<0.01)$, while the Tb.Sp was lower in the high-dose group than that in the low-dose group $(P<0.05)$.

Effect of genistein-treatment on the mRNA expression of ALP, OC, OPG, RANKL, ER $\alpha$, and ERß in vivo

As shown in Figure 3, gene expression of ALP, OC, OPG, ERa, and ER $\beta$ increased in the low-dose genistein-treated group (all $P<0.01)$ compared with the control group, but that of RANKL decreased $(P<0.01)$. In the high-dose genistein-treated group, however, the gene expression of ALP, OC, OPG, RANKL, and ERa decreased significantly (all $P<0.01$ ), but that of ER $\beta$ still increased compared with the control group $(P<0.01)$. Gene expression of ALP, OC, OPG, and ERa in the low-dose genistein-treated group was higher than that in the highdose group (all $P<0.01$ ). Additionally, the RANKL/OPG ratio decreased in both genistein-treated groups.

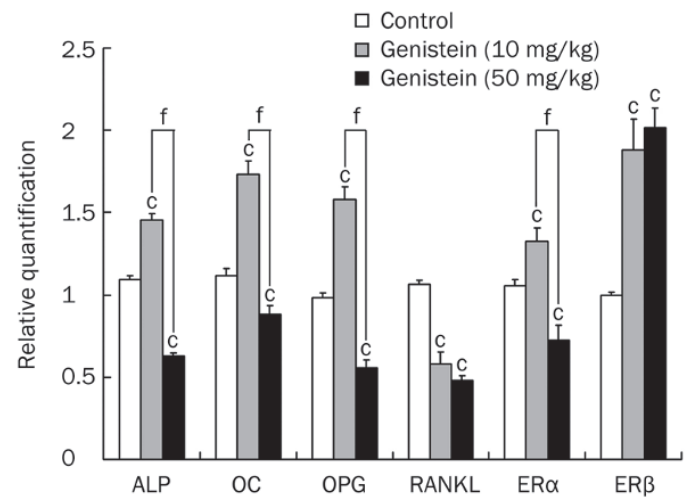

Figure 3. Effect of genistein treatment on the mRNA expression of ALP, OC, OPG, RANKL, ER $\alpha$, and ER $\beta$. Values were normalized to the expression of S18. Data shown are mean $\pm S D(n=3) .{ }^{c} P<0.01$ indicates significant difference between genistein-treatment and control groups. ${ }^{f} P<0.01$ indicates significant difference between high and low dose genisteintreatment groups.
Effect of genistein-treatment on serum levels of bone-ALP, OC, OPG, RANKL, and CTX

Compared with the control group, the serum b-ALP, OC, and OPG levels increased significantly (all $P<0.01$ ), but the sRANKL level decreased $(P<0.01)$ in the low-dose genisteintreated group (Table 3 ). No significant difference was found in the CTX level between control and low-dose genisteintreated groups. However, compared with the control group, not only the serum sRANKL and CTX (both $P<0.01$ ), but also b-ALP, OC, and OPG levels decreased $(P<0.05, P<0.05$, and $P<0.01$, respectively) in the high-dose genistein-treated group. The serum b-ALP, OC, OPG, and CTX levels in the low-dose genistein-treated group were higher than those in the highdose group $(P<0.01, P<0.01, P<0.01$, and $P<0.05$, respectively). The RANKL/OPG ratio decreased in both genistein-treated groups (Table 4 ).

Table 4. Values of serum bone markers after genistein treatment. Mean \pm SEM. ${ }^{b} P<0.05,{ }^{c} P<0.01$ vs control group. ${ }^{e} P<0.05,{ }^{f} P<0.01$ vs low dose $(10 \mathrm{mg} / \mathrm{kg})$ genistein-treatment groups.

\begin{tabular}{lccc}
\hline Parameters & Control group & $\begin{array}{c}\text { Genistein } \\
(10 \mathrm{mg} / \mathrm{kg})\end{array}$ & $\begin{array}{c}\text { Genistein } \\
(50 \mathrm{mg} / \mathrm{kg})\end{array}$ \\
\hline b-ALP $(\mathrm{U} / \mathrm{L})$ & $118.00 \pm 9.90$ & $151.33 \pm 9.01^{\mathrm{c}}$ & $98.93 \pm 13.02^{\mathrm{bf}}$ \\
OC $(\mathrm{ng} / \mathrm{mL})$ & $9.95 \pm 1.27$ & $13.93 \pm 2.55^{\mathrm{c}}$ & $\begin{array}{c}7.76 \pm 1.73^{\mathrm{bf}} \\
\text { OPG }(\mathrm{pg} / \mathrm{mL})\end{array}$ \\
SRANKL $(\mathrm{pg} / \mathrm{mL})$ & $22.53 \pm 3.18$ & $13.15 \pm 2.17^{\mathrm{c}}$ & $11.64 \pm 2.56^{\mathrm{c}}$ \\
CTX $(\mathrm{ng} / \mathrm{mL})$ & $53.93 \pm 7.49$ & $49.40 \pm 8.07$ & $38.46 \pm 6.62^{\mathrm{ce}}$ \\
\hline
\end{tabular}

b-ALP, bone alkaline phosphatase; sRANKL, soluble receptor activator of nuclear factor $\mathrm{KB}$ ligand.

Effect of genistein-treatment on the mRNA expression of ALP, $O C, O P G, R A N K L, E R \alpha$, and ERß in vitro

As shown in Figure 4, genistein affected osteoblasts from mandibular condylar subchondral bone in a concentrationdependent manner. The presence of $10^{-7} \mathrm{~mol} / \mathrm{L}$ genistein in 


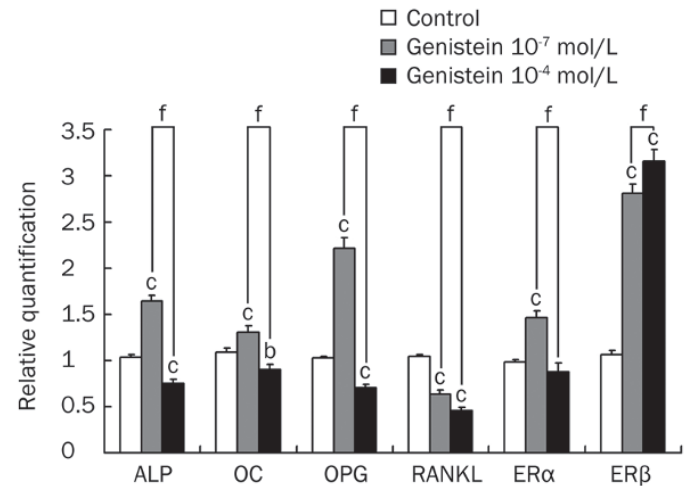

Figure 4. Effect of genistein treatment on the mRNA expression of ALP, $\mathrm{OC}, \mathrm{OPG}, \mathrm{RANKL}$ in osteoblasts. Values were normalized to the expression of $18 \mathrm{~S}$. Data shown are mean $\pm \mathrm{SD}(n=3) .{ }^{\mathrm{b}} P<0.05,{ }^{\mathrm{c}} P<0.01$ indicate significant difference between genistein treatment and control group. ${ }^{f} P<0.01$ indicates significant difference between high and low dose genistein-treatment groups.

the culture medium induced a significant decrease in the gene expression of RANKL $(P<0.01)$, as well as increase in ALP, OC, OPG, ERa, and ER $\beta$ (all $P<0.01$ ). However, the presence of $10^{-4} \mathrm{~mol} / \mathrm{L}$ genistein reduced the expression of ALP, OC, OPG, RANKL $(P<0.01, P<0.05, P<0.01$, and $P<0.01$, respectively), as well as increase in ER $\beta$ expression $(P<0.01)$. The expression of ALP, OC, OPG, RANKL and ERa in the $10^{-7} \mathrm{~mol} / \mathrm{L}$ genisteintreated group were higher than those in the $10^{-4} \mathrm{~mol} / \mathrm{L}$ group (all $P<0.01$ ). Alternatively, expression of ER $\beta$ was lower in the low-dose group than in the high-dose group (both $P<0.01$ ). The RANKL/OPG ratio was decreased by both $10^{-4}$ and $10^{-7}$ $\mathrm{mol} / \mathrm{L}$ genistein treatment, respectively.

\section{Effect of ER silencing on the effect of genistein treatment}

In order to explore the function of ER $\alpha$ and ER $\beta$, we performed gene silencing experiments in osteoblasts. The mRNA levels of ERa and ER $\beta$ were decreased in cells as detected by real-time PCR (Figure 5). ERa and ER $\beta$ siRNA were able to knockdown $72 \%$ and $80 \%$ of ER expression, respectively. As shown in Figure 6 and Figure 7, ER $\beta$ silencing reversed the effect of both $10^{-7}$ and $10^{-4} \mathrm{~mol} / \mathrm{L}$ genistein treatment in the expression of ALP, OC, OPG, and RANKL. ERa silencing only reversed the expression of ALP and OPG (both $P<0.01$ ) in

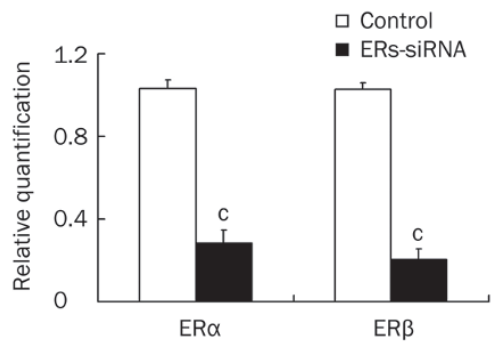

Figure 5. Effect of $E R \alpha$ and $E R \beta$ siRNA on the mRNA expression of ER $\alpha$ and ERB in osteoblasts. Values were normalized to the expression of $18 \mathrm{~S}$. Data shown are mean $\pm \operatorname{SD}(n=3) .{ }^{c} P<0.01$ vs control.

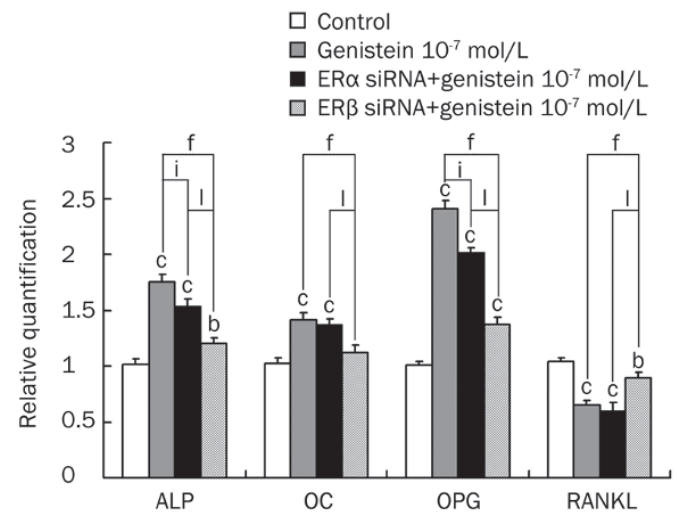

Figure 6. Effect of ER $\alpha$ and ER $\beta$ silencing on the expression of ALP, OC, OPG, RANKL in osteoblasts treated by $10^{-7} \mathrm{~mol} / \mathrm{L}$ genistein. Values were normalized to the expression of $18 \mathrm{~S}$. Data shown are mean $\pm \operatorname{SD}(n=3)$. ${ }^{\mathrm{b}} P<0.05,{ }^{\mathrm{c}} P<0.01$ indicate significant difference between genistein treatment and control group. ${ }^{f} P<0.01$ indicates significant difference between $10^{-7} \mathrm{~mol} / \mathrm{L}$ genistein-treatment group and $\mathrm{ER} \alpha \operatorname{siRNA}+10^{-7}$ $\mathrm{mol} / \mathrm{L}$ genistein-treatment group. ${ }^{i} P<0.01$ indicates significant difference between $10^{-7} \mathrm{~mol} / \mathrm{L}$ genistein-treatment group and ER $\beta$ siRNA $+10^{-7}$ $\mathrm{mol} / \mathrm{L}$ genistein-treatment group. ${ }^{1} P<0.01$ indicates significant difference between $\mathrm{ER} \alpha \mathrm{siRNA}+10^{-7} \mathrm{~mol} / \mathrm{L}$ genistein-treatment group and $\mathrm{ER} \beta$ SiRNA $+10^{-7} \mathrm{~mol} / \mathrm{L}$ genistein-treatment group.

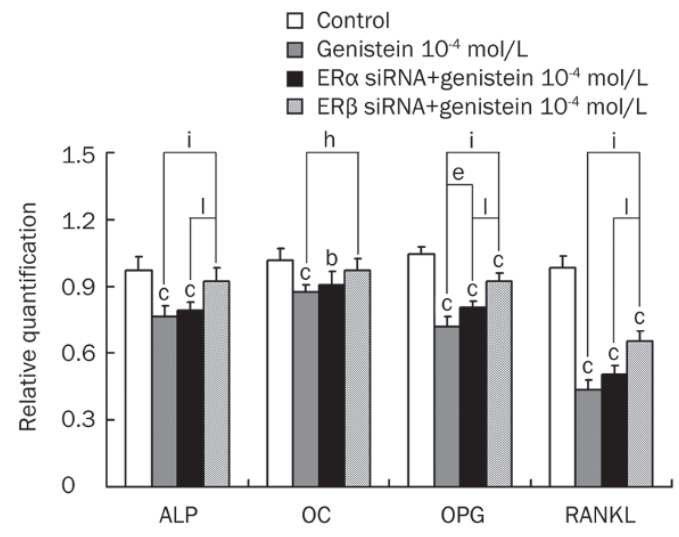

Figure 7. Effect of ER $\alpha$ and ERß silencing on the expression of ALP, OC, OPG, RANKL in osteoblasts treated by $10^{-4} \mathrm{~mol} / \mathrm{L}$ genistein. Values were normalized to the expression of 18S. Data shown are mean \pm SD $(n=3)$. ${ }^{\mathrm{b}} P<0.05,{ }^{\mathrm{c}} P<0.01$ indicate significant difference between genistein treatment and control group. ${ }^{\mathrm{e}} P<0.05$ indicates significant difference between $10^{-4} \mathrm{~mol} / \mathrm{L}$ genistein-treatment group and ER $\alpha \mathrm{siRNA}+10^{-4} \mathrm{~mol} / \mathrm{L}$ genistein-treatment group. ${ }^{h} P<0.05,{ }^{i} P<0.01$ indicate significant difference between $10^{-4} \mathrm{~mol} / \mathrm{L}$ genistein-treatment group and ER $\beta$ siRNA $+10^{-4}$ $\mathrm{mol} / \mathrm{L}$ genistein-treatment group. ${ }^{\prime} P<0.01$ indicates significant difference between $\mathrm{ER} \alpha \mathrm{siRNA}+10^{-4} \mathrm{~mol} / \mathrm{L}$ genistein-treatment group and $\mathrm{ER} \beta$ SiRNA $+10^{-4} \mathrm{~mol} / \mathrm{L}$ genistein-treatment group.

$10^{-7} \mathrm{~mol} / \mathrm{L}$ genistein-treatment group, and that of OPG in the $10^{-4} \mathrm{~mol} / \mathrm{L}$ genistein-treated group $(P<0.05)$. Importantly, the effect of ER $\beta$ silencing was greater than that of ERa silencing in nearly all of the groups with the exception of OC expression in the $10^{-4} \mathrm{~mol} / \mathrm{L}$ genistein-treated group (all $P<0.01$ ). 


\section{Discussion}

In the literature, the protective effects of genistein in OVX rats and mice preventing OVX-induced bone loss have been reported in appendicular bone or vertebrae for various treatment periods (2-15 weeks), application routes (oral gavage, intraperitoneal administration, subcutaneous administration) and doses of genistein $\left(3-50 \mathrm{mg} \cdot \mathrm{kg}^{-1} \cdot \mathrm{d}^{-1}\right)^{[18,20,30-36]}$. Similarly, oral administration of genistein $\left(54 \mathrm{mg} \cdot \mathrm{kg}^{-1} \cdot \mathrm{d}^{-1}\right)$ increased BMD of the spine and hip in osteopenic postmenopausal Caucasian women with an observation period of 24 months ${ }^{[17]}$. In the present study on female rats with normal estrogen levels, both low and high doses of genistein treatment were observed to induce significant increase in BMD, BMC and bone volume, as well as inducing thicker and larger trabecular bone in the mandibular subchondral bone. These results were consistent with the above-mentioned studies on appendicular bone or vertebrae ${ }^{[17,18,20,30-36]}$, indicating that the effect of genistein on mandibular subchondral bone is similar to that on appendicular bone or vertebrae.

Similar to the biphasic effects of estrogen depending on dosage $^{[37]}$, genistein was also observed to have a biphasic cell proliferative response, stimulation at low concentrations and inhibition at high concentrations ${ }^{[38-40]}$. In the present study low dose genistein treatment increased the expression of ALP, OC, and OPG at the serum level and mRNA level both in vivo and in vitro. Low-dose genistein treatment also decreased the expression of RANKL and the RANKL/OPG ratio in agreement with previous studies ${ }^{[20,41-44]}$. These data suggest that normal doses of genistein improve bone formation and inhibit bone resorption. However, high-dose genistein treatment decreased not only the expression of RANKL and the RANKL/OPG ratio, but also that of ALP, OC, and OPG. It indicates that excess genistein inhibits both bone resorption and bone formation in rat mandibular subchondral bone. This phenomenon is consistent with the fact that the number of both active osteoclasts and active osteoblasts is increased in postmenopausal osteoporosis induced by estrogen deficiency ${ }^{[45]}$. Although bone formation was also inhibited by excess genistein, the RANKL/OPG ratio was still lower in the high-dose genistein-treated group than in the control group, which is in line with the increased BMD and bone volume in the high-dose genistein-treated group. Interestingly, though bone formation was inhibited by excess genistein to some extent, high doses of genistein induced more mandibular subchondral trabecular bone compared to low-dose genistein. This discrepancy might be due to the sampling time-point, or the asynchronism between microstructural parameters and the expression of bone homeostasis-associated factors. Allowing for these considerations, further studies with additional timepoints are needed.

A mechanism has been proposed in which genistein affects bone homeostasis directly via ER activation in bone ${ }^{[34]}$. The two subtypes of ER, ERa, and ER $\beta$, are distinct proteins encoded by separate genes located on different chromosomes. Genistein is almost exclusively ER $\beta$ selective and binds with a 7- to 30-fold greater affinity to ER $\beta$ than to $\mathrm{ERa}^{[40]}$. Further- more, genistein activates transcriptional activation of ER $\beta$ at a 10-fold lower concentration than for $\mathrm{ERa}^{[40]}$. In the present study, the expression of ER $\beta$ was increased significantly by both low and high doses of genistein, while the expression of ERa was increased by low dose of genistein, but decreased by high dose of genistein. Furthermore, ER $\beta$ silencing reversed the effect of genistein treatment on the expression of ALP, OC, OPG, and RANKL. The effect of ER $\beta$ silencing was greater than that of ERa silencing. It seems that the effect of genistein on rat mandibular subchondral bone was preferentially mediated via ER $\beta$ activation, which is in keeping with the previous report that the effect of genistein on skeletal muscle myosin heavy chain expression was predominantly mediated through $E R \beta^{[46]}$.

In the literature, a few studies support ERa's involvement in the adaptive response of osteoblasts to mechanical strain ${ }^{[47-50]}$. $\mathrm{ERa}-/$ - mice produced three times less new cortical bone in response to the same mechanical stimulus as their ERa+/+ littermates ${ }^{[47,48]}$. Similarly, osteoblasts derived from ERa-/mice failed to increase in number in response to mechanical stimulation, which can be rescued by transfection with fully functional $\mathrm{ERa}^{[49,50]}$. The decreased expression of ERa in the high-dose genistein-treated group may imply a decreased adaptive capacity of mandibular subchondral bone to mechanical loads. Considering the difference and fluctuation of estrogen levels in individual people, the proper dose of genistein should be studied in more depth prior to wide application of genistein in the treatment of osteoporosis or OA.

In summary, low-dose genistein can increase bone formation and inhibit bone resorption, while excess genistein can inhibit both bone resorption and bone formation in rat mandibular condylar subchondral bone, which was predominantly mediated through $E R \beta$.

\section{Acknowledgements}

The authors thank Mr Jun WANG (Xijing Hospital, Fourth Military Medical University) for technical assistance in microCT. This work was financially supported by the National Natural Science Foundation of China (№ 30901699 and № 30928028).

\section{Author contribution}

Shi-bin YU and Guang-ying DONG designed the present study and wrote the manuscript. Yong-qi LI performed the animal treatments, sample preparation and micro-CT analysis. Xiang-hui XING performed the ELISA assay, PCR and revised the manuscript. Hui WANG performed the osteoblast culture, ER silencing and PCR in vivo. Xi-li WENG performed the HE staining, data analysis and revised the manuscript.

\section{References}

1 Hohenhaus MH, McGarry KA, Col NF. Hormone therapy for the prevention of bone loss in menopausal women with osteopenia: is it a viable option? Drugs 2007; 67: 2311-21.

2 Levine JP. Effective strategies to identify postmenopausal women at risk for osteoporosis. Geriatrics 2007; 62: 22-30. 
3 Fitzpatrick LA. Estrogen therapy for postmenopausal osteoporosis. Arq Bras Endocrinol Metabol 2006; 50: 705-19.

4 Nevitt MC, Cummings SR, Lane NE, Hochberg MC, Scott JC, Pressman $A R$, et al. Association of estrogen replacement therapy with the risk of osteoarthritis of the hip in elderly white women. Study of Osteoporotic Fractures Research Group. Arch Intern Med 1996; 156: 2073-80.

5 Zhang Y, McAlindon TE, Hannan MT, Chaisson CE, Klein R, Wilson PW, et al. Estrogen replacement therapy and worsening of radiographic knee osteoarthritis: the Framingham Study. Arthritis Rheum 1998; 41: 1867-73.

6 Spector TD, Nandra D, Hart DJ, Doyle DV. Is hormone replacement therapy protective for hand and knee osteoarthritis in women? The Chingford Study. Ann Rheum Dis 1997; 56: 432-4.

7 Stevenson JC. Hormone replacement therapy: review, update, and remaining questions after the Women's Health Initiative Study. Curr Osteoporos Rep 2004; 2: 12-6.

8 Collaborative Group on Hormonal Factors in Breast Cancer. Breast cancer and hormone replacement therapy: collaborative reanalysis of data from 51 epidemiological studies of 52,705 women with breast cancer and 108,411 women without breast cancer. Lancet 1997; 350: $1047-59$.

9 Million Women Study Collaborators. Breast cancer and hormonereplacement therapy in the Million Women Study. Lancet 2003; 362: 419-27.

10 Setchell KD, Lydeking-Olsen E. Dietary phytoestrogens and their effect on bone: evidence from in vitro and in vivo, human observational, and dietary intervention studies. Am J Clin Nutr 2003; 78: 593S-609S.

11 Messina M, Ho S, Alekel DL. Skeletal benefits of soy isoflavones: a review of the clinical trial and epidemiologic data. Curr Opin Clin Nutr Metab Care 2004; 7: 649-58.

12 Chanawirat A, Khemapech S, Patumraj S, Siriviriyakul P. Genistein replacement therapy on endothelial dysfunction and bone loss in bilateral ovariectomized rats. Clin Hemorheol Microcirc 2006; 34: 309-14.

13 Erlandsson MC, Islander U, Moverare S, Ohlsson C, Carlsten H. Estrogenic agonism and antagonism of the soy isoflavone genistein in uterus, bone and lymphopoiesis in mice. APMIS 2005; 113: 317-23.

14 Chen YM, Ho SC, Lam SS, Ho SS, Woo JL. Beneficial effect of soy isoflavones on bone mineral content was modified by years since menopause, body weight, and calcium intake: a double-blind, randomized, controlled trial. Menopause 2004; 11: 246-54.

15 Wu J, Oka J, Higuchi M, Tabata I, Toda T, Fujioka M, et al. Cooperative effects of isoflavones and exercise on bone and lipid metabolism in postmenopausal Japanese women: a randomized placebo-controlled trial. Metabolism 2006; 55: 423-33.

16 Morabito N, Crisafulli A, Vergara C, Gaudio A, Lasco A, Frisina N, et al. Effects of genistein and hormone-replacement therapy on bone loss in early postmenopausal women: a randomized double-blind placebocontrolled study. J Bone Miner Res 2002; 17: 1904-12.

17 Marini H, Minutoli L, Polito F, Bitto A, Altavilla D, Atteritano M, et al. Effects of the phytoestrogen genistein on bone metabolism in osteopenic postmenopausal women: a randomized trial. Ann Intern Med 2007; 146: 839-47.

$18 \mathrm{Li} \mathrm{B}$, Yu S. Genistein prevents bone resorption diseases by inhibiting bone resorption and stimulating bone formation. Biol Pharm Bull 2003; 26: 780-6.

19 Sliwiński L, Folwarczna J, Nowińska B, Cegieła U, Pytlik M, Kaczmarczyk-Sedlak I, et al. A comparative study of the effects of genistein, estradiol and raloxifene on the murine skeletal system. Acta Biochim Pol 2009; 56: 261-70.

20 Bitto A, Burnett BP, Polito F, Marini H, Levy RM, Armbruster MA, et al. Effects of genistein aglycone in osteoporotic, ovariectomized rats: a comparison with alendronate, raloxifene and oestradiol. $\mathrm{Br} J$ Pharmacol 2008; 155: 896-905.

21 Tähtelä R, Thölix E. Serum concentrations of type I collagen carboxyterminal telopeptide (ICTP) and type I procollagen carboxy-and aminoterminal propeptides (PICP, PINP) as markers of metastatic bone disease in breast cancer. Anticancer Res 1996; 16: 2289-93.

22 Shoji K, Elsubeihi ES, Heersche JN. Effects of ovariectomy on turnover of alveolar bone in the healed extraction socket in rat edentulous mandible. Arch Oral Biol 2011; 56: 114-20.

23 Jonasson G, Alstad T, Vahedi F, Bosaeus I, Lissner L, Hakeberg M. Trabecular pattern in the mandible as bone fracture predictor. Oral Surg Oral Med Oral Pathol Oral Radiol Endod 2009; 108: e42-51.

24 Griffin CJ, Powers R, Kruszynski R. The incidence of osteoarthritis of the temporomandibular joint in various cultures. Aust Dent J 1979; 24: 94-106.

25 Milam SB. Pathophysiology and epidemiology of TMJ. J Musculoskelet Neuronal Interact 2003; 3: 382-90.

26 Jiao K, Dai J, Wang MQ, Niu LN, Yu SB, Liu XD. Age- and sex-related changes of mandibular condylar cartilage and subchondral bone: a histomorphometric and micro-CT study in rats. Arch Oral Biol 2010; 55: 155-63.

27 Michael MR, Wolz E, Davidovich A, Pfannkuch F, Edwards JA, Bausch J. Acute, subchronic and chronic safety studies with genistein in rats. Food Chem Toxicol 2006; 44: 56-80.

28 Seibel J, Molzberger AF, Hertrampf T, Laudenbach-Leschowski U, Diel P. Oral treatment with genistein reduces the expression of molecular and biochemical markers of inflammation in a rat model of chronic TNBS-induced colitis. Eur J Nutr 2009; 48: 213-20.

29 Viereck V, Gründker C, Blaschke S, Siggelkow H, Emons G, Hofbauer LC. Phytoestrogen genistein stimulates the production of osteoprotegerin by human trabecular osteoblasts. J Cell Biochem 2002; 84: 725-35.

30 Ishida H, Uesugi T, Hirai K, Toda T, Nukaya H, Yokotsuka K, et al. Preventive effects of the plant isoflavones, daidzin and genistin, on bone loss in ovariectomized rats fed a calcium-deficient diet. Biol Pharm Bull 1998; 21: 62-6.

31 Nakajima D, Kim CS, Oh TW, Yang CY, Naka T, Igawa S, et al. Suppressive effects of genistein dosage and resistance exercise on bone loss in ovariectomized rats. J Physiol Anthropol Appl Human Sci 2001; 20 : 285-91.

32 Ye SF, Saga I, Ichimura K, Nagai T, Shinoda M, Matsuzaki S. Coumestrol as well as isoflavones in soybean extract prevent bone resorption in ovariectomized rats. Endocr Regul 2003; 37: 145-52.

33 Pie JE, Park JH, Park YH, Ryu YM, Kim KN, Suh SW, et al. Effect of genistein on the expression of bone metabolism genes in ovariectomized mice using a cDNA microarray. J Nutr Biochem 2006; 17: 157-64.

34 Hertrampf T, Gruca MJ, Seibel J, Laudenbach U, Fritzemeier KH, Diel P. The bone-protective effect of the phytoestrogen Genistein is mediated via $E R \alpha$-dependent mechanisms and strongly enhanced by physical activity. Bone 2007; 40: 1529-35.

35 Hertrampf T, Schleipen B, Offermanns C, Velders M, Laudenbach U, Diel P. Comparison of the bone protective effects of an isoflavone-rich diet with dietary and subcutaneous administrations of genistein in ovariectomized rats. Toxicol Lett 2009; 184: 198-203.

36 Dai R, Ma Y, Sheng Z, Jin Y, Zhang Y, Fang L, et al. Effects of genistein on vertebral trabecular bone microstructure, bone mineral density, microcracks, osteocyte density, and bone strength in ovariectomized rats. J Bone Miner Metab 2008; 26: 342-9.

37 Cheng P, Ma X, Xue Y, Li S, Zhang Z. Effects of estradiol on proliferation and metabolism of rabbit mandibular condylar cartilage cells in 
vitro. Chin Med J (Engl) 2003; 116: 1413-7.

38 Maggiolini M, Bonofiglio D, Marsico S, Panno ML, Cenni B, Picard D, Ando S. Estrogen receptor $\alpha$ mediates the proliferative but not the cytotoxic dose-dependent effects of two major phytoestrogens on human breast cancer cells. Mol Pharmacol 2001; 60: 595-602.

39 Power KA, Thompson LU. Ligand-induced regulation of ER $\alpha$ and ER $\beta$ is indicative of human breast cancer cell proliferation. Breast Cancer Res Treat 2003; 82: 209-21.

40 Rajah TT, Du N, Drews N, Cohn R. Genistein in the presence of 17betaestradiol inhibits proliferation of ERbeta breast cancer cells. Pharmacology 2009; 84: 68-73.

41 Marini H, Minutoli L, Polito F, Bitto A, Altavilla D, Atteritano M, et al. OPG and SRANKL serum concentrations in osteopenic, postmenopausal women after 2-year genistein administration. J Bone Miner Res 2008; 23: 715-20.

42 Crisafulli A, Altavilla D, Squadrito G, Romeo A, Adamo EB, Marini R, et al. Effects of the phytoestrogen genistein on the circulating soluble receptor activator of nuclear factor kappaB ligand-osteoprotegerin system in early postmenopausal women. J Clin Endocrinol Metab 2004; 89: 188-92.

43 Zhang Y, Li Q, Wan HY, Helferich WG, Wong MS. Genistein and a soy extract differentially affect three-dimensional bone parameters and bone-specific gene expression in ovariectomized mice. J Nutr 2009; 139: 2230-6.
$44 \mathrm{Ha} \mathrm{H}$, Lee HY, Lee JH, Jung D, Choi J, Song KY, et al. Formononetin prevents ovariectomy-induced bone loss in rats. Arch Pharm Res 2010; 33: 625-32.

45 Lerner UH. Bone remodeling in post-menopausal osteoporosis. J Dent Res 2006; 85: 584-95.

46 Velders M, Solzbacher M, Schleipen B, Laudenbach U, Fritzemeier KH, Diel P. Estradiol and genistein antagonize the ovariectomy effects on skeletal muscle myosin heavy chain expression via ER-beta mediated pathways. J Steroid Biochem Mol Biol 2010; 120:53-9.

47 Lee K, Jessop H, Suswillo R, Zaman G, Lanyon L. Endocrinology: bone adaptation requires oestrogen receptor-alpha. Nature 2003; 424: 389.

48 Lee KC, Jessop H, Suswillo R, Zaman G, Lanyon LE. The adaptive response of bone to mechanical loading in female transgenic mice is deficient in the absence of oestrogen receptor-alpha and -beta. J Endocrinol 2004; 182: 193-201.

49 Jessop HL, Suswillo RF, Rawlinson SC, Zaman G, Lee K, Das-Gupta $\mathrm{V}$, et al. Osteoblast-like cells from estrogen receptor alpha knockout mice have deficient responses to mechanical strain. J Bone Miner Res 2004; 19: 938-46.

50 Zaman G, Cheng MZ, Jessop HL, White R, Lanyon LE. Mechanical strain activates estrogen response elements in bone cells. Bone 2000; 27: 233-9. 